\title{
REVIEW
}

\section{Visual and taste cues for minimising native bird interactions with toxic 1080 baits - a review of current practices}

\author{
Phil Cowan $^{1 *}$ and Michelle Crowell ${ }^{2}$ \\ ${ }^{1}$ Landcare Research, PO Box 69040, Lincoln 7640, New Zealand \\ ${ }^{2}$ Department of Conservation, Science and Policy Group, Private Bag 4715, Christchurch 8041, New Zealand \\ *Author for correspondence (Email: cowanp@landcareresearch.co.nz)
}

Published online: 7 February 2017

\begin{abstract}
Non-target risk from the use of vertebrate toxins for pest control is an ongoing issue globally. In New Zealand, toxic bait for aerial control of possums and rodents is dyed green and contains cinnamon oil, both of which are thought to reduce the risk that birds will eat the bait. It has been suggested for some time that blue dye may be a more effective feeding deterrent than green dye. While both green and blue dye reduce the risk that birds will feed on bait, the available evidence is not sufficiently strong to suggest a significant improvement in repelling birds by switching from green to blue. Cinnamon oil, at the nominal concentration in bait, may have some bird repellent effects, but these are likely to depend on its origin (bark or leaves) and the freshness of the bait (as it evaporates relatively quickly from bait after manufacture). Bait colour, including ultraviolet, is also an important cue in avoidance learning by birds and should be considered in more detail in future studies of specific bird repellent additives to bait for possum and rodent control. Further research is needed to optimise the use of visual cues in bait, both for their inherent repellency (e.g. green vs blue; optimal concentration of dye) and for their effectiveness in promoting avoidance learning. It would also be worth investigating an alternative compound to cinnamon as a mask for 1080; ideally such an alternative would have enhanced stability and bird repellent properties.
\end{abstract}

Keywords: bait colour; bird repellent; cinnamon; non-target risks; possums; rats

\section{Background information}

Non-target risk from use of vertebrate toxins for pest control is an ongoing issue globally. The addition of dye to impart colour to bait has been researched for more than 125 years to minimise those risks, particularly to avian species (Kalmbach 1943; Williams 1958). In New Zealand, extensive control of pest mammals by aerial poisoning with sodium fluoroacetate (1080) or brodifacoum to mitigate impacts of introduced possums (Trichosurus vulpecula) and rodents (Rattus spp.) on native biodiversity and agriculture seeks increasingly to minimise risks to non-target species, especially native birds (Spurr 2000; Wright 2011). Risk mitigation is needed because a wide range of native species is susceptible to the vertebrate toxins used (Eason et al. 2011). In New Zealand, much of the risk mitigation has been indirect, through changes in the way aerial poisoning is undertaken (such as cluster and strip sowing techniques) and significant reductions in the amount of toxic bait used (Nugent et al. 2011; Nugent \& Morriss 2013). However, recently there have been renewed efforts to identify chemical repellents that could be added to bait to directly reduce the risk that native birds will eat bait and ingest a lethal dose of 1080 (Clapperton et al. 2014; Cowan et al. 2015, 2016; Crowell et al. 2016a, b). This research has examined both primary repellents (acting through unpleasant taste, smell or irritant properties) and secondary repellents (causing an unpleasant physiological response soon after ingestion), and strategies that involve combinations of the two types.

The principal method still used for reducing risk to nontarget species remains dying bait a colour that is considered to reduce the risk that non-target species will ingest it. Currently, toxic bait for aerial control of possums and rodents is dyed green as that is thought to act as a primary repellent and/or camouflage and therefore reduce the risk that birds will eat the bait. Use of green dye also makes it easy to visually discriminate toxic bait from non-toxic prefeed (Williams 1958). Bait produced today routinely uses V200 green dye (B Simmons, M Thomas, pers. comm.) but until the mid-1980s the dye of choice was Lissamine Green, which was a much brighter green than V200 (B Simmons, pers. comm.). The concentration of green dye in commercially produced bait is usually $0.3-0.8 \%$ (B Simmons, M Thomas, pers. comm.). The blue dye used is usually indigo carmine (B Simmons, pers. comm.). Blue dye is often used in baits containing anticoagulant toxins, such as brodifacoum, but whether that is primarily for bird protection or to aid discrimination from 1080 baits, or both, is not clear. Toxic bait also contains cinnamon oil as a mask for the taste/ smell of 1080 to possums; this has often been suggested to also have bird-repellent effects (Udy \& Pracey 1981; Pracy et al. 1982).

Questions regarding the relative efficacy of green and blue dye and cinnamon as bird repellents were raised over a decade ago. Brown and Ulrich (2005) reviewed parameters affecting the efficacy of aerial 1080 operations for possum and rat control and concluded that research was required on the relative benefits of using green- and blue-dyed baits for protection of native birds. Blue dye was suggested as an alternative because some research (Hartley et al. 1999, 2000; Clapperton et al. 2012) indicated blue dye was more effective than green in deterring some bird species from feeding on bait. 
Therefore in the interests of best practice aerial poisoning to reduce non-target impacts, we summarise available literature on colour and taste aversions related to avoidance of 1080 bait by target and non-target species, particularly birds; comment on the implications of our findings for best practice aerial control of possums; and identify future research needs.

\section{Colour vision, colour preferences and colour use as a learning cue in birds}

How birds perceive colour and any natural colour preferences that they have are highly relevant to selection of an appropriate colour to minimise bait uptake. Colour vision is common among avian species, but differs from that of humans in two ways. First, diurnal birds, as are most New Zealand bird species, are able to see ultraviolet (UV) light. Second, bird species have at least four types of receptors for colour processing (cones), while humans have three. While UV reception increases the range of wavelengths over which birds can see, the sensation provided by four cone types produces a qualitative change in the nature of bird colour perception such that the colours birds see are not simply refinements of the hues seen by humans (Tanaka 2015). Colour perception is a complex interaction of achromatic and chromatic contrasts between an object and its spectral background. Chromatic signals (hue) are mostly derived from the light's wavelength. Achromatic signals (brightness) are mostly derived from the light's energy at a certain wavelength (i.e. intensity of the colour; for example, dark or light red) (Fadzly et al. 2013).

Colour preferences of birds have been much studied, particularly in relation to colours of natural foods, especially fruits (e.g. Willson et al. 1990; Lord et al. 2002; Stournaras et al. 2013; Duan et al. 2014). Fruits eaten by birds are often red or black and rarely orange, yellow, green or brown (Janson 1983; Willson et al. 1989). While in most experiments bird species show consistent preferences for fruits or dyed baits of particular colours, in some colour preferences varied (Willson et al. 1990; Duan \& Quan 2013; Fadzly et al. 2013; Weser \& Ross 2013) or there were no significant preferences (Byrant et al. 1984). The contrast between the colour of a fruit and the background against which it is displayed may also influence bird colour preferences (Behbahaninia et al. 2012; Camargo et al. 2013; Duan \& Quan 2013) and the low contrast of green fruit against a green background may in part explain why few bird-dispersed plants have green fruits (Camargo et al. 2013). Individual birds within a species may show different colour preferences depending on gender (Mastrota \& Mench 1994), and colour preferences may be changed, at least in the short term, by prior exposure to coloured food (Willson et al. 1990; Larrinaga 2011; Behbahaninia et al. 2012). Colour preferences may also vary depending on food type (e.g. fruit vs insect; Gamberale-Stille et al. 2007). While natural or green-dyed fruits or test baits appear generally to be less preferred than those of other colours (Brunner \& Coman 1983; Rathore 1985; Mastrota \& Mench 1994; Moran 1999; Weser \& Ross 2013), the variation noted in responses suggests, as Kalmbach and Welch (1946) did in general terms, that there are potential differences between bird species in response to colours. Therefore, before any change of bait colour is proposed, more research is needed on the responses of the most at-risk New Zealand native birds to differently-coloured baits, as few species and limited colours have been tested to date.
Bait colour is also important as a visual cue as part of strategies that involve the addition of secondary repellent compounds to bait. Bait colour has been shown experimentally to be an effective cue for avoidance learning by birds by promoting stronger aversion or more rapid learning, although again this may vary between species (Bullard et al. 1983; Mason \& Reidinger 1983a, b; Nelms \& Avery 1997; Nicholls et al. 2000; Werner et al. 2008; Werner \& Provenza 2011). Bait colour thus has a potential influence on the efficacy of secondary repellents that might be added to bait for aerial control of possum and rats to minimise uptake by birds. At least for red-winged blackbirds (Agelaius phoeniceus), preand post-ingestive consequences appear to be associated with visual cues, while visual and gustatory experience appear to be integrated with post-ingestive consequences in the process of learning to avoid toxic substances (Werner et al. 2008; Werner \& Provenza 2011). More generally, Werner and Clark (2003) suggested colour may be the dominant cue in avoidance learning for granivorous birds and so visual cues might enhance the efficacy of repellent compounds. However, the problem of choice of effective colour remains. Weser and Ross's (2013) review of studies investigating food colour preferences found significant variation across a wide range of species, although green and blue were among the most commonly avoided colours. For some bird species, taste cues may enhance or potentiate learned avoidance to visual cues (Lett 1980).

Birds appear to differ from mammals in that colour is often a more effective cue for avoidance learning than taste or odour (Mason \& Reidinger 1983a; Greig-Smith \& Rowney 1987; Nelms \& Avery 1997; Werner et al. 2008) although, for some bird species, simultaneous taste cues strengthen avoidance compared to visual cues alone (Lett 1980). Mason and Reidinger (1983b) found that stronger food aversion learning was shown by red-winged blackbirds to food dyed shades of red than green and that generalisation of avoidance learning to other shades was stronger for red than green. Martin and Lett (1985) suggested that birds that selected food based on taste relied more on flavour than colour when forming aversions to foods, whereas those that ate relatively tasteless foods relied more on colour. Trials with red-winged blackbirds showed that the birds associated pre- and post-ingestive consequences with visual cues, and reliably combined visual and gustatory cues with post-ingestive consequences to select foods and avoid toxins (Werner et al. 2008: Werner \& Provenza 2011). The recent demonstrations (Werner et al. 2012, 2014a, b) that a UV cue paired with a post-ingestive repellent could be used to condition food avoidance in red-winged blackbirds and wild turkeys provides new opportunities to develop effective cues for aversion learning in birds that may not be effective in mammals. This could be of particular relevance to the New Zealand situation where the aim is to repel native birds from feeding on toxic bait, but not the target animals, possums and rats. However, as noted above, taste seems to be a more salient cue than colour for learned avoidance by mammals.

\section{Green dye to minimise New Zealand bird interactions with toxic bait}

The inclusion of green dye in bait for aerial control of possums is based on largely qualitative trials of responses of domestic fowls (Gallus gallus domesticus) and introduced quail (Callipepla californica), sparrows (Passer domesticus) and 
finches (Fringillidae) to dyed foods (Williams 1958; Caithness $\&$ Williams 1971). Those trials led to a specification for green dye in toxic baits of a colour within the range 221-225 (Standard 381C, British Standards Institution 1964). Subsequently, Henderson and Frampton (1999) assessed the effects of five different green dyes (including V200 green currently used to dye bait) at a concentration that met the shade of green legally required at the time and found no negative effect on the palatability of cereal bait to possums. They recommended a colour range of 221-267 by the New Zealand Standard Specification 7702 (section 23, New Zealand Standards 1965). Since then the use of a green dye has generally been standard operational practice for aerial poisoning, although the current New Zealand hazardous substances controls specify only that bait must be dyed either green or blue. However, details of product formulation, including dye, must be lodged with the New Zealand Environmental Protection Agency, and each trade name product registration under the Agricultural Compounds and Veterinary Medicines (ACVM) Act 1997 has a specified confidential product formulation.

Caithness and Williams (1971) based their studies on acceptability of baits dyed different colours to birds in New Zealand on earlier observations that green-dyed (and to a lesser extent yellow-dyed) bait greatly reduced bird feeding on toxic grain baits for rodent control (Kalmbach 1943; Kalmbach \& Welch 1946). Kalmbach (1943, p. 414) stated: 'On the basis of work done (with a variety of bird species) ... most pronounced aversion manifests itself with respect to foods dyed with colors near the center of the humanly visible spectrum, in the yellow and green sectors ...'. This statement implies that the deterrent effect of green dye in bait is probably an unlearned (innate) response (see also Mastrota \& Mench 1994), as is also implied in much of the literature about natural colour preferences of food selected by birds (e.g. Willson et al. 1989). If that assumption is correct, green colour is not acting as a typical primary repellent where mode of action is usually through unpleasant taste or smell or irritant properties. However, Kalmbach (1943) and Kalmbach and Welch (1946) both cautioned that aversion to green may be overcome by hunger and that reaction to colour may differ not only between species but also between males and females of a species; they further suggest a need to determine hues of optimum deterrent effectiveness for individual bird species.

Despite the use of green dye in bait for aerial possum and rodent control for more than 30 years, the experimental evidence for its efficacy in deterring birds from eating bait is equivocal. Determining the efficacy of green dye is confounded because cinnamon oil is usually also included in such bait, and it is also reported to act as a primary bird repellent (Udy \& Pracey 1981). As noted above, the original trials by Caithness and Williams (1971) were of very limited scope and did not test any native New Zealand birds. Udy and Pracey (1981) offered free-living weka (Gallirallus australis) cereal pellets of different colours; orange, yellow, blue, and black were preferred over green. They also tested the various types of bait on free-living water birds; plain green-dyed cereal pellets were eaten but those lured with cinnamon were mostly rejected, as was cinnamon-treated bread. Spurr (1993) offered a range of captive, rare native birds fresh carrot pieces and cereal-based pellets (both dyed green with $0.02 \%$ acid brilliant green) for up to 7 days. Although most birds ate only a few baits or parts of baits, all birds ate some dyed bait, probably sufficient to cause lethal poisoning if the bait had been toxic (Spurr 1993). Hickling (1997) found that captive kaka (Nestor meridionalis) sampled green-dyed cereal pellet bait (RS5, $0.1 \%$ cinnamon oil, V200 dye) and undyed bait (RS5, no cinnamon, no green dye) to similar extents for a couple of days before a strong preference for plain bait developed. Empson and Miskelly (1999) found that free-living weka $(70 \% ; n=30)$, robins (Petroica longipes) $(56 \% ; \mathrm{n}=34)$, saddlebacks (Philesturnus rufusater $)(27 \% ; \mathrm{n}=11)$ and little spotted kiwi (Apteryx owenii) $(7 \% ; n=29)$ ate some experimentally-laid, non-toxic Wanagui No. 7 (W7) cereal pellet baits surface-coated with green dye (type not specified). In 34 encounters with handmade W7 baits dyed green with $0.1 \%$ V200 green and surface-coated with $0.1 \%$ cinnamon oil, none of seven kiwi picked up the baits, although they did occasionally sniff or probe at them (Ward-Smith \& Potter 1999). Styche and Speed (2002) presented free-living robins with a choice of cinnamon-lured, non-toxic RS5 cereal pellets (dyed with green food colouring) and various other bait matrices on areas scraped free of leaf litter. Although robins spent long periods foraging at the test sites, only $10 \%$ of robins pecked at the RS5 baits. Ross et al. (2002) offered free-living birds a choice between non-toxic W7 cereal bait containing $0.075 \%$ V200 green dye and $0.1 \%$ cinnamon oil and one of four other green-dyed bait types at replicated ground feeding stations. Limited observations of birds at the stations recorded feeding on bait by kākāriki (Cyanoramphus novaezelandiae), robin, fantail (Rhipidura fuliginosa), pūkeko (Porphyrio porphyrio) and quail (Callipepla californica). More W7 bait was eaten in each trial than each of the other four test baits.

Despite the limited scope of testing and the confounding effects of added cinnamon oil, overall the evidence to date suggests green dye has at least some, albeit unquantified, efficacy in minimising risks that native birds will eat dyed bait. There would appear to be scope for further research to confirm this effect and to optimise the colour, hue and brightness of green dye added to bait.

\section{Alternative dye colours to minimise New Zealand bird interactions with toxic bait}

Blue dye has been suggested as an alternative to green dye to minimise non-target risk from baits used for aerial control of possums based on both the natural colour preferences of birds and some experimental trials. Naturally occurring blue fruits, while more common than green ones, are much less common than red/orange or purple/black fruits (Lord \& Marshall 2001), and generally less preferred than red or black in choice tests (e.g. Brunner \& Coman 1983; Larrinaga 2011; Duan \& Quan 2013). In assessing risks prior to a proposed aerial poisoning operation, Oppel et al. (2016) found that Henderson crakes (Zapornia atra) ate no dry pellets but less moistened blue-dyed cereal pellet bait than green-dyed bait. There was considerable individual variation among birds but, on average, males ate much less blue than green bait than did females. Interestingly, two other experimental studies reported that bird species tested avoided blue-dyed food even when it was not paired with a repellent, and suggested the blue colour may even have been a more aversive agent than the repellents tested (quinine sulphate, methiocarb, dinol sulphite, TS-69, tannic acid, see Greig-Smith \& Rowney 1987; 4-aminoacetophenone, see Nicholls et al. 2000). Blue-dyed baits have been tested for acceptability on only three species of New Zealand birds, free-living North Island robins, and captive weka and kea (Nestor notabilis) (Hartley et al. 1999, 2000; Weser \& Ross 2013). Robins pecked 
increasingly less at brown-, light-blue-, medium-blue-, red-, green- and yellow-dyed bait, although there were consistent differences in colour preference between individual birds. Weka ate less green-, mid-blue-, light-blue- and brown-dyed food pellets on the first day of testing than red and yellow pellets, but consumption of pellets of all colours increased sharply on subsequent days, presumably because there were no postingestive consequences. Kea ate green-dyed food the least, and increasing amounts of dark-blue-, mid-blue-, brown-, red- and yellow-dyed food. Considering the small number of species tested and the variation in responses, there is no compelling evidence yet that blue dye would be more effective than green dye in deterring native birds from eating baits for possum and rodent control. It also remains unknown whether blue would be a more effective colour cue for avoidance learning than green.

Any proposed change in the colour of bait for aerial control to minimise risk to non-target species must also be assessed for potential effects on efficacy of control of the target species. Increasingly, the primary targets of such control are both possums and rats, so potential consequences must be considered for both species. Change of colour from green to blue appears unlikely to affect bait take by possums. Day and Matthews (1999) found no difference in acceptability or palatability of non-toxic or toxic commercial cereal bait with V200 green dye compared with the same bait surface-coated with yellow or blue non-flavoured powdered food dyes (Bush Boake Allen NZ Ltd) mixed with water $(2 \% \mathrm{w} / \mathrm{w})$. Surprisingly, there is little published information about rat responses to differently coloured baits. Lund (1988) listed blue, green, red, and black as the most common colours of dyes used in rodent baits, but did not comment on their acceptability or palatability. Prakash et al. (2003) found that ship rats ( $R$. rattus) preferred greendyed bait to blue, black or undyed bait. Overall, Salmon and Dochtermann (2006) found that Norway rats ( $R$. norvegicus) ate similar amounts of food dyed black, blue or red, although consumption of food treated with one of the blue dyes declined significantly over the three days of testing, suggesting learned aversion. Rats are often referred to as colour-blind (e.g. Meehan 1984), leading to the frequently-stated assumption that rat baits can be dyed distinctive colours without causing avoidance, as long as the dye does not have an objectionable taste or odour. However, it is now known that the retina of $R$. norvegicus is sensitive to green and blue-ultraviolet, that Norway rats can perceive ultraviolet light, and, with training, they can distinguish between ultraviolet and visible light, and between different colours in the blue-green range(Walton 1933; Jacobs et al. 2001; Burn 2008). Regardless, colour cues may not be very important to rats, as brightness appears to be far more important; it is much easier to train rats to behaviourally differentiate brightness than to behaviourally differentiate colours (Jacobs et al. 2001).

\section{Cinnamon oil}

Since the early 1980 s cinnamon oil $(0.1-0.3 \%)$ has been routinely added to cereal baits for aerial control of possums and rodents to mask the odour and taste of 1080 to possums (Morgan 1990) and is also thought to act as a primary repellent to feeding by birds (Udy \& Pracey 1981; Pracy etal. 1982). New Zealand bait manufacturers appear to use a mixture of cinnamon oil from different sources, but were reluctant to disclose further information for commercial reasons. Henderson and Frampton (1999) recommended an optimal manufacturing concentration of $0.2 \%$ (with limits of $0.1-<0.5 \%$ ), and this value was adopted in the quality standards for 1080 pellet bait by the Department of Conservation (Eason \& Wickstrom 2001). Cinnamon is lost rapidly from cereal bait after manufacture, stabilising at about $40 \%$ of nominal concentration after 8 weeks (Henderson \& Frampton 1999), so its 1080-masking and bird-deterrent effects are expected to be reduced in aged baits. The Department of Conservation's current best practice guidelines specify $0.3 \%$ $\mathrm{w} / \mathrm{w}$ cinnamon oil to address the problem of lure dissipation (Department of Conservation 2016).

Udy and Pracey (1981) offered free-living native birds (principally kaka and weka) crumbled orange-dyed cereal bait mixed with various lure and flavour additives at 1.67 parts per million; one of the two additives rejected by weka was cinnamon. Kaka offered dates with one out of every five coated with cinnamon at the same concentration rejected only the cinnamon-treated dates (Udy \& Pracey 1981). Udy and Pracy also offered water birds green-dyed cereal pellets with or without cinnamon; pellets treated with cinnamon were mostly rejected, as was cinnamon-treated bread. Cinnamon oil $(0.1 \%$ or $1 \%)$ added to their normal diet did not deter captive kiwi from feeding, although at $1 \%$, one of the five birds ate all the untreated food first (McLennan et al. 1992). The birds in Spurr's (1993) study were also offered bait surface-sprayed with $0.1 \%$ cinnamon oil. Some birds of all species ate some cinnamon-treated bait, but usually after a 1-2 day delay that was not seen with untreated bait. In the same trial, kaka offered a favoured food (dates) treated with cinnamon oil, picked up and dropped the baits without feeding when they were first offered. Spurr (1993) noted a rapid decay in the odour of cinnamon from the baits and suggested an increased concentration should be used, or it should be incorporated in the cereal bait mixture (the latter suggestion is now standard practice). Day et al. (2003) observed North Island robins pecking at baits including cinnamon, and Orr-Walker et al. (2012) concluded that cinnamon oil at the concentrations used in cereal bait was not an effective feeding deterrent for kea.

Cinnamon oil extracted from leaves contains mostly eugenol(the main constituent of clove oil) whereas that extracted from bark contains mostly cinnamaldehyde (Senanayake et al. 1978; Li et al. 2013). Both these compounds and some of the other constituents that occur in low concentrations are known to have bird repellent effects (e.g. Jakubas et al. 1992; Clark 1995; Watkins et al. 1999). Cinnamaldehyde was the most effective bird repellent of 14 cinnamic acid derivatives tested by Watkins et al. (1999), including cinnamamide, which has been extensively evaluated for field use (Cowan et al. 2016). The efficacy of eugenol is less well studied and it has been evaluated mostly as an insect repellent. However, Eugenol may play a useful role if it deters invertebrates from feeding on the bait, as secondary poisoning of native adult and nestling birds through eating toxin-contaminated insects is a demonstrated risk (Lloyd \& McQueen 2000; Masuda et al. 2014).

Therefore, the use of cinnamon oil from bark would seem more likely to have bird feeding deterrent effects than that from leaves. Cinnamon oil is usually incorporated in bait at $0.15-0.3 \%$. At the concentration of cinnamaldehyde in oil from bark reported by Senanayake et al. (1978), cereal pellet bait could contain about $0.11-0.23 \%$ cinnamaldehyde. When the closely related cinnamamide is included at a concentration of $0.25 \%$ it reduces, but does not eliminate, feeding by a number of bird species, although at that concentration it may also reduce feeding by target rodents (Cowan et al. 2016). 


\section{Synthesis and recommendations}

Conclusions about the relative efficacy of green and blue dye with and without the addition of cinnamon in reducing the risk of poisoning from cereal bait used for aerial control of possum and rats are hampered by several factors. First, many of the trials were conducted on small samples of captive birds, and so may not have been representative of the responses of freeliving bird populations (Esther et al. 2011). Second, the trials on New Zealand birds tested efficacy of different colours only as deterrents to feeding, not as cues for avoidance learning. Third, most of the original reports on which the choice of additives is based provide little or no details on key aspects of methodology - identity of the dye (dyes may vary in spectral signature); concentration of dye used (which may affect bait palatability and/or contrast with background); how baits were presented (e.g. choice or no-choice trials); what background baits were presented on (potentially influencing bait visibility/novelty); source of cinnamon oil (leaf or bark); sample sizes; and how the responses of test birds or bait acceptability/rejection were measured. The background against which baits are presented may be of particular significance. Udy and Pracey (1981) noted that weka did not find or ignored baits dyed to approximately match the colour of grass when they were scattered on grass. Willson etal. (1990) and Allen et al. (1990) recorded differences in preferences of frugivorous birds for coloured foods when they were presented on different backgrounds, with baits on a similar coloured background selected less often.

Regardless of uncertainty about the relative efficacy of different dyes and cinnamon oil, monitoring of field operations demonstrates the efficacy of current practice in minimising native bird deaths. Monitoring of numerous recent (post-1998) aerial control operations using green-dyed bait with cinnamon for their impact on native bird populations has demonstrated that mortality is minor in most cases (Veltman \& Westbrooke 2011; Wright 2011; Veltman et al. 2014; Morriss et al. 2016). However, Veltman and Westbrooke (2011) concluded from their meta-analysis that apart from kiwi, kaka and kōkako, low risk from aerial poisoning could not be assumed for other native bird species because of inadequate information. For the few native birds for which non-target deaths remain a specific concern, for example kea, a high risk may be restricted to a subset of the population in which natural cautious behaviour toward novel objects/foods has been modified by prior experience with humans and human paraphernalia (J Kemp, pers. comm.) and additional or alternative protective tactics may be required.

The extent to which any reduction in risk to native birds can be attributed to the use of dyed bait and cinnamon rather than recent improvements in bait quality and huge reductions in bait sowing rates is unclear. Regardless, there is strong ongoing social pressure to better address the general issue of non-target risks from possum control (Green \& Rohan 2012), which has been accompanied by a decline in public support for the use of toxins such as 1080, particularly when applied aerially (Russell 2014). This, as Russell (2014) suggests, could lead to additional conflict given the recent increased use of aerial 1080 by the Department of Conservation in its Battle for our Birds Program (www.doc.govt.nz/our-work/battlefor-our-birds) and its use in current proposals for landscape scale eradication of possums and other small mammal pests (Parkes et al. 2017).

Other than the trials by Pracy et al. (1982), there has been little research on responses of New Zealand birds to alternative bait additives except for the known bird repellents anthraquinone and d-pulegone (Clapperton et al. 2012; OrrWalker et al. 2012; Cowan et al. 2015). Pracy et al. (1982) tested 20 flavours on free-living weka. These were presented at a concentration of $0.5 \%(\mathrm{v} / \mathrm{w})$ in crumbled yellow-dyed wholemeal in random sets of four at seven locations over 3 -day periods. Those flavours judged non-acceptable to weka were screened subsequently for acceptability to free-living possums. Groups of free-living kaka were also offered dates with (c. 1.6\%) and without various flavours rejected by weka. These results were used to extend a list of flavours considered acceptable to possums but unacceptable to weka and kaka; these were almond, bayleaf, bergamot, clove, cinnamon, eucalyptus, gingerine, lemon, nutmeg, peppermint, pimento leaf and spearmint. Other than cinnamon, none appear to have been further evaluated empirically as bird-repellent additives to bait for aerial 1080 poisoning of possums and rodents.

Currently, non-toxic prefeed for aerial poisoning is occasionally dyed green but toxic pellets are always dyed green. For the innate deterrent action of green dye to be most effective, green dye should not be used on prefeed, as those birds that eat some green-dyed prefeed and suffer no postingestional consequences may have an increased likelihood of subsequently eating green-dyed toxic bait, as the behaviour of the weka in Hartley et al. (2000)'s trial suggests. However, a different strategy is necessary if colour is to be used as a cue for avoidance learning. As Cowan et al. (2016) pointed out, birds exposed to aerial poisoning with prefeeding show one of four behaviours: (1) ignore all bait; (2) eat prefeed but not toxic bait; (3) do not eat prefeed but eat toxic bait; and (4) eat prefeed and toxic bait. Minimising non-target deaths requires a strategy to minimise type (3) and (4) responses. At present the mortality risk to type (3) responders is reduced by inclusion of green dye as a feeding deterrent in the toxic bait, but inclusion of primary repellent would provide additional protection.

The potential strategy for a species showing a type (4) response is more complex; it could involve the same or different primary repellents in prefeed and toxic bait; a secondary repellent with appropriate cues for avoidance learning in prefeed and a primary repellent with the same cues in toxic bait; or both primary and secondary repellents in prefeed with appropriate cues for avoidance learning and a primary repellent with the same cues in toxic bait. At the moment it is unclear if the cues provided by current prefeed bait (undyed, cinnamon) are sufficient for the development of learned avoidance should secondary repellent be included in prefeed, or if the efficacy of the learned response could be improved with different cues. Some learning of pellet-associated cues was demonstrated by captive native kea, which ate less pellet bait with cinnamon pre-exposure to similar pellets containing anthraquinone and/ or d-pulegone than post-exposure (Orr-Walker et al. 2012). However, relative to plain wheat, the amount of blue-dyed wheat with anthraquinone eaten by sparrows was not further reduced by the addition of cinnamon, suggesting little role for cinnamon as a learning cue (Clapperton et al. 2012). Currently, baits are dyed a uniform colour; countershading (i.e. darker dye on surfaces most exposed to light), for example, may further reduce bait uptake (Rowland et al. 2007), but may not be practicable to implement.

Regarding green versus blue colour for possum and rat bait, the available evidence does not appear to be sufficiently strong to suggest an improvement in repellency to birds from switching to blue, and, therefore, further trials comparing 
responses of native birds to blue vs green dyed bait with and without a secondary repellent are probably warranted. A switch to blue dye would require a new approval from the Ministry of Primary Industries under the ACVM Act as a change in formulation. In addition, the current small knowledge base about responses to blue-dyed bait under operational conditions would limit assessment of the likely environmental impacts of proposed control operations.

Future research should focus on the need to optimise the use of visual cues in bait for their inherent repellency to native birds. This will require assessing the responses of the most at-risk New Zealand native birds to bait of different colours (visual vs UV) of varying hue and brightness, as few species and limited colours have been tested to date. Research is also needed into the relative effectiveness of different colour dyes for bait in promoting avoidance learning to maximise the efficacy of added primary and or secondary repellent compounds. While the addition of cinnamon to bait plays a key role in minimising taste aversion to 1080 , its role as a bird repellent requires further clarification. Because cinnamon oil is relatively expensive and volatile there would be value in seeking alternative masking compounds, particularly if those also had proven bird-repellent efficacy.

\section{Acknowledgements}

Thanks are due to Bill Simmons and Malcolm Thomas for information about cereal pellet bait manufacture. Penny Fisher, Bruce Warburton and Alastair Fairweather and two anonymous referees provided helpful comments on the manuscript, which was edited by Leah Kearns. Funding for the review was provided by the New Zealand Ministry for Business, Innovation and Employment.

\section{References}

Allen JA, Anderson KP, Tucker GM 1990. An improved method for demonstrating visual selection by wild birds. Journal of Biological Education 24: 262-266.

Behbahaninia H, Butler MW, Toomery MB, McGraw KJ 2012. Food color preferences against a dark, textured background vary in relation to sex and age in house finches (Carpodacus mexicanus). Behaviour 149: 51-65.

British Standards Institution 1964. Colours for specific purposes: BS 381C. London, British Standards.

Brown KP, Ulrich SC 2005. Aerial 1080 operations to maximise biodiversity protection. Research and Development Series, No. 216. Wellington, New Zealand, Department of Conservation. $36 \mathrm{p}$.

Brunner H, Coman BJ 1983. The ingestion of artificially coloured grain by birds and its relevance to vertebrate pest control. Australian Wildlife Research 10: 303-310.

Bryant H, Hone J, Nicholls P 1984. The acceptance of dyed grain by feral pigs and birds. Australian Wildlife Research 11: 509-516.

Bullard RW, Bruggers RL, Kilburn SR, Fielder LA 1983. Sensory-cue enhancement of the bird repellency of methiocarb. Crop Protection 2: 387-398.

Burn CC 2008. What is it like to be a rat? Rat sensory perception and its implications for experimental design and rat welfare. Applied Animal Behaviour Science 112: 1-32.
Caithness TA, Williams GR 1971. Protecting birds from poison baits. New Zealand Journal of Agricultural Research 122: $38-43$.

Camargo MGG, Cazetta E, Schaefer HM, Morellato LP 2013. Fruit color and contrast in seasonal habitats - a case study from a cerrado savannah. Oikos 122: 1335-1342.

Clapperton BK, Porter RER, Day TM, Waas JR, Matthews LR 2012. Designer repellents: combining olfactory, visual or taste cues with a secondary repellent to deter free-ranging house sparrows from feeding. Pest Management Science 68: 870-877.

Clapperton BK, Morgan DKJ, Day TD, Oates KE, Beath AM, Matthews LR 2014. Efficacy of bird repellents at deterring North Island robins (Petroica australis longipes) and tomtits (P. macrocephala toitoi) from baits. New Zealand Journal of Ecology 38: 116-123.

Clark L 1995. A review of the bird repellent effects of 117 carbocyclic compounds. In: Mason JR ed. Proceedings of the Repellents in Wildlife Management Conference. Ft Collins, Colorado. Pp. 343-352.

Cowan P, Brown S, Forrester G, Booth L, Crowell M 2015. Bird-repellent effects on bait efficacy. Pest Management Science 71: 1075-1081.

Cowan P, Booth L, Crowell M 2016. Repellents with potential to protect kea and other native birds from aerial poisoning for possum and rat control. New Zealand Journal of Ecology 40: 29-41.

Crowell M, Booth L, Cowan P, Fairweather A, Westbrooke I 2016a. Stability of bird repellents used to protect kea (Nestor notabilis) during aerial 1080 cereal operations. New Zealand Journal of Ecology 40: 42-48.

Crowell M, Martini M, Moltchanova E 2016b. Effect of the addition of bird repellents to aerially applied 1080 baits on rat and possum abundance. New Zealand Journal of Ecology 40: 49-59.

Day TD, Matthews LR 1999. Do colours that deter birds affect cereal bait acceptance by possums (Trichosurus vulpecula)? New Zealand Journal of Ecology 23:261-266.

Day TD, Matthews LR, Waas JR 2003. Repellents to deter New Zealand's North Island robin Petroica australis from pest control baits. Biological Conservation 114:309-316.

Department of Conservation 2016. Method best practice for Battle for our Birds aerial 1080 baiting. Version 1.2. Hamilton, New Zealand, Department of Conservation. $4 \mathrm{p}$.

Duan Q, Quan R-C 2013. The effect of color on fruit selection in six tropical Asian birds. The Condor 115: 623-629.

Duan Q, Goodale E, Quan R-C 2014. Bird fruit preferences match the frequency of fruit colours in tropical Asia. Scientific Reports 4: 5627.

Eason CT, Wickstrom M 2001. Vertebrate pesticide toxicology manual (poisons). New Zealand Department of Conservation Technical Series 23. Wellington, New Zealand, Department of Conservation. 122 p.

Eason C, Miller A, Ogilvie S, Fairweather A 2011. An updated review of the toxicology and ecotoxicology of sodium fluoroacetate (1080) in relation to its use as a pest control tool in New Zealand. New Zealand Journal of Ecology 35: $1-20$.

Empson RA, Miskelly CM 1999. The risks, costs and benefits of using brodifacoum to eradicate rats from Kapiti Island, New Zealand. New Zealand Journal of Ecology 23: 241-254.

Esther A, Tilcher R, Jacob J 2011. Assessing the effects of three potential chemical repellents to prevent bird damage 
to corn seeds and seedlings. Pest Management Science 69: 425-430.

Fadzly N, Burns KC, Zuharah WF 2013. Evaluating frugivorefruit interactions using avian eye modelling. Tropical Life Sciences Research 24: 31-50.

Gamberale-Stille G, Hall KSS, Tullberg BS 2007. Signals of profitability? Food colour preferences in migrating juvenile blackcaps differ for fruits and insects. Evolutionary Ecology 21: 99-108.

Green W, Rohan M 2012. Opposition to aerial 1080 poisoning for control of invasive mammals in New Zealand: risk perceptions and agency responses. Journal of the Royal Society of New Zealand 42: 185-213.

Greig-Smith PW, Rowney CM 1987. Effects of colour on the aversions of starlings and house sparrows to five chemical repellents. Crop Protection 6: 402-409.

Hartley L, O'Connor C, Waas J, Matthews L 1999. Colour preferences in North Island robins (Petroica australis); implications for deterring birds from poisonous baits. New Zealand Journal of Ecology 23: 255-259.

Hartley L, Waas J, O’Connor C, Matthews L 2000. Colour preferences and coloured bait consumption by weka Gallirallus australis, an endemic New Zealand rail. Biological Conservation 93: 255-263.

Henderson RJ, Frampton CM 1999. Avoiding bait shyness in possums by improved bait standards. Lincoln, Landcare Research Contract Report LC9899/060. 6 p.

Hickling GJ 1997. Effect of green dye and cinnamon oil on consumption of cereal pest baits by captive North Island kaka (Nestor meridionalis). New Zealand Journal of Zoology 24: 239-242.

Jacobs GH, Fenwick JA, Williams GA2001. Cone-based vision of rats for ultraviolet and visible lights. The Journal of Experimental Biology 204: 2439-2446.

Jakubas WJ, Shah PS, Mason RJ, Norman DM 1992. Avian repellency of coniferyl and cinnamyl derivatives. Ecological Applications 2: 147-156.

Janson CH 1983. Adaptation of fruit morphology to dispersal agents in a neotropical forest. Science 219: 87-189.

Kalmbach ER 1943. Birds, rodents and colored lethal baits. Transaction of the North American Wildlife Conference 8: 408-416.

Kalmbach ER, Welch JF 1946. Colored rodent baits and their value in safeguarding birds. Journal of Wildlife Management 10: 353-360.

Larrinaga AR 2011. Inter-specific and intra-specific variability in fruit color preference in two species of Turdus. Integrative Zoology 6: 244-258.

Lett BT 1980. Taste potentiates color-sickness associations in pigeons and quail. Animal Learning and Behaviour 8: $193-198$

Li Y-Q, Kong D-X, Wu H 2013. Analysis and evaluation of essential oil components of cinnamon barks using GC-MS and FTIR spectroscopy. Industrial Crops and Products 41: 269-278.

LloydBD, McQueen SM2000. An assessment of the probability of secondary poisoning of forest insectivores following an aerial 1080 possum control operation. New Zealand Journal of Ecology 24: 47-56.

Lord JM, Marshall J 2001. Correlations between growth form, habitat, and fruit colour in the New Zealand flora, with reference to frugivory by lizards. New Zealand Journal of Botany 39: 567-576.

Lord JM, Markey AS, Marshall J 2002. Have frugivores influenced the evolution of fruit traits in New Zealand? In: Levey DJ, Silva WR, Galetti M eds. Seed dispersal and frugivory: ecology, evolution and conservation. New York, CAB Publishing. Pp. 55-80.

Lund M 1988. Selection of baits and their distribution. In: Prakash I ed. Rodent pest management. Boca Raton, Florida, CRC Press. Pp. 331-340.

McLennan J, Porter D, Cowan P 1992. Compounds to prevent non-target animals from eating poisonous baits laid for possums. Department of Scientific and Industrial Research, Land Resources, Contract Report 92/55. 14 p.

Martin GM, LettBT 1985. Formation of associations of colored and flavoured food with induced sickness in five avian species. Behavioral and Neural Biology 43: 223-237.

Mason JR, Reidinger RF 1983a. Importance of color for methiocarb-induced food aversions in red-winged blackbirds. Journal of Wildlife Management 47: 383-393.

Mason JR, Reidinger RF 1983b. Generalization of and effects of pre-exposure on color-avoidance learning by red-winged blackbirds (Agelaius phoeniceus). The Auk 100: 461-468.

Mastrota FN, Mench JA 1994. Avoidance of dyed food by the northern bobwhite. Applied Animal Behaviour Science 42: 109-119.

Masuda BM, Fisher P, Jamieson IG 2014. Anticoagulant rodenticide brodifacoum detected in dead nestlings of an insectivorous passerine. New Zealand Journal of Ecology 38: $110-115$.

Meehan AP 1984. Rats and mice: their biology and control. East Grinstead, UK, Rentokil Ltd. 383 p.

Moran S 1999. Rejection of dyed field rodent baits by feral pigeons and Chukar partridges. Phytoparasitica 27:9-17.

Morgan DR 1990. Behavioural response of brushtail possums, Trichosurus vulpecula, to baits used in pest control. Australian Wildlife Research 17: 601-613.

Morriss GA, Nugent G, Whitford J 2016. Dead birds found after aerial poisoning operations targeting small mammal pests in New Zealand 2003-14. New Zealand Journal of Ecology 40: 361-370.

Nelms Co, Avery ML 1997. Reducing bird repellent application rates by the addition of sensory stimuli. International Journal of Pest Management 43: 187-190.

New Zealand Standards 1965. New Zealand Standards Act 1965.www.nzlii.org/nz/legis/hist_act/sa19651965n59139 (accessed 18 March 2016).

Nicholls MK, Love OP, Bird DM 2000. An evaluation of methyl anthranilate, aminoacetophenone and unfamiliar coloration as feeding repellents to American kestrels. Journal of Raptor Research 34: 311-318.

Nugent G, Morriss GA2013. Delivery of toxic bait in clusters: a modified technique for aerial poisoning of small mammal pests. New Zealand Journal of Ecology 37: 246-255.

Nugent G, Warburton B, Thomson C, Sweetapple P, Ruscoe WA 2011. Effect of prefeeding, sowing rate and sowing pattern on efficacy of aerial 1080 poisoning of small-mammal pests in New Zealand. Wildlife Research 38: 249-259.

Oppel S, Lavers JL, Bond AL, Harrison G 2016. Reducing the primary exposure risk of Henderson crakes (Zapornia atra) during aerial broadcast eradication by selecting appropriate bait colour. Wildlife Research 43: 298-303.

Orr-Walker T, Adams NJ, Roberts LG, Kemp JR, Spurr EB 2012. Effectiveness of the bird repellents anthraquinone and d-pulegone on an endemic New Zealand parrot, the kea(Nestornotabilis). Applied Animal Behaviour Science 137: 80-85. 
Parkes JP, Nugent G, Forsyth DM, Byrom AE, Pech RP, Warburton B, Choquenot D 2017. Pest, present and two potential futures for managing New Zealand's mammalian pests. New Zealand Journal of Ecology 41: 1-22.

Pracy LT, Robertson BA, Udy PB 1982. Flavours tested on Kapiti. Counterpest 8: 10-11.

Prakash S, Kumar S, Veer V, Gopalan N, Purnanand, Pandey KS, Rao KM 2003. Laboratory evaluation of four rodenticides admixed in a cereal-based bait against commensal rat, Rattus rattus (L.) (Rodentia: Muridae: Murinae). Journal of Stored Products Research 39: 141-147.

RathoreAK 1985. Influence of 1080 bait colour on acceptability by target species and removal by non-target animals. Australian Rangelands Journal 7: 140-142.

Ross J, Henderson R, Griffiths J 2002. Measuring interference with possum baits by native birds. Lincoln University, New Zealand, Project R-80562 Report to Animal Health Board. 12 p.

Rowland HM, Speed MP, Ruxton GD, Edmunds M, Stevens M, Harvey IF 2007. Countershading enhances cryptic protection: an experiment with wild birds and artificial prey. Animal Behaviour 74: 1249-1258.

Russell JC 2014. Acomparison of attitudes towards introduced wildlife in New Zealand in 1994 and 2012. Journal of the Royal Society of New Zealand 44: 136-151.

Salmon TP, Dochtermann NA 2006. Rodenticide grain bait ingredient acceptance by Norway rats (Rattus norvegicus), California ground squirrels (Spermophilus beecheyi) and pocket gophers (Thomomys bottae). Pest Management Science 62: 678-683.

Senanayake UM, Lee TH, Wills RBH 1978. Volatile constituents of cinnamon (Cinnamomum zeylanicum) oils. Journal of Agricultural and Food Chemistry 26: 822-824.

Spurr EB 1993. Feeding by captive rare birds on baits used in poisoning operations for control of brushtail possums. New Zealand Journal of Ecology 17: 13-18.

Spurr E2000. Impacts of possum control on non-target species. In: Montague TLed. The brushtail possum: biology, impact and management of an introduced marsupial. Lincoln, Manaaki Whenua Press. Pp. 175-186.

Stournaras KE, Lo E, Bohning-Gaese K, Cazetta E, Dehling DM, Schleuning M, Stoddard MC, Donoghue MJ, Prum RO, Schaefer HM 2013. How colourful are fruits? Limited color diversity in fleshy fruits on local and global scales. New Phytologist 198: 617-629.

StycheA, Speed H 2002. Rodent bait preferences in non-target birds. DOC Science Internal Series No. 40. Wellington, Department of Conservation. $12 \mathrm{p}$.

Tanaka KD 2015. A colour to birds and humans: why is it so different? Journal of Ornithology 156: 433-440.

Udy PB, Pracey LT 1981. Baits, birds and field operations. Counterpest 6: 13, 15.

Veltman CJ, Westbrooke IM 2011. Forest bird mortality and baiting practices in New Zealand aerial 1080 operations from 1986 to 2009. New Zealand Journal of Ecology 35: 21-29.
Veltman CJ, Westbrooke IM, Powlesland RG, Greene TC 2014. A principles-based decision tree for future investigations of native New Zealand birds during aerial 1080 operations. New Zealand Journal of Ecology 38: 103-109.

Walton WE 1933. Color vision and color preference in the albino rat. II. The experiments and results. Comparative Psychology 15: 373-394.

Ward-Smith T, Potter M 1999. Response of wild kiwi to orange and cinnamon lured possum baits. Conservation Advisory Science Notes No. 259. Wellington, Department of Conservation. $9 \mathrm{p}$.

Watkins RW, Lumley JA, Gill EL, Bishop JD, Langton SD, MacNicoll AD, Price NR, Drew MGB 1999. Quantitative structure-activity relationships (QSAR) of cinnamic acid bird repellents. Journal of Chemical Ecology 25: 2825-2845.

Werner SJ, Clark L 2003. Understanding blackbird sensory systems and how repellent applications work. In: Linz GM ed. Management of North American blackbirds. Proceedings of a Special Symposium of the Wildlife Society 9th Annual Conference. Pp. 31-40.

Werner SJ, Provenza FD 2011. Reconciling sensory cues and varied consequences of avian repellents. Physiology and Behavior 102: 158-163.

Werner SJ, Kimball BA, Provenza FD 2008. Food color, flavour, and conditioned avoidance among red-winged blackbirds. Physiology and Behavior 93: 110-117.

Werner SJ, Tupper SK, Carlson JC, Pettit SE, Ellis JW, Linz GM 2012. The role of a generalized ultraviolet cue for blackbird food selection. Physiology and Behavior 106: 597-601.

Werner SJ, Buchholz R, Tupper SK, Pettit SE, Ellis JW 2014a. Functional significance of ultraviolet feeding cues in wild turkeys. Physiology and Behavior 123: 162-167.

Werner SJ, deLiberto ST, Pettit SE, Mangan AM 2014b. Synergistic effects of an ultraviolet feeding cue for an avian repellent and protection of agricultural crops. Applied Animal Behaviour Science 159: 107-113.

Weser C, Ross JG 2013. The effect of colour on bait consumption of kea (Nestor notabilis); implications for deterring birds from toxic baits. New Zealand Journal of Zoology 40: 137-144.

Williams GR 1958. Summary of colour bait experiments. Proceedings of the Meeting to Discuss the Noxious Animal Problem in New Zealand. Wellington, New Zealand Forest Service. Pp. 41-42.

Willson MF, Irvine AK, Walsh NG 1989. Vertebrate dispersal syndromes in some Australian and New Zealand plant communities, with geographic comparisons. Biotropica 21: $133-147$.

Willson MF, GraffDA, Whelan CJ 1990. Color preferences of frugivorous birds in relation to the colors of fleshy fruits. The Condor 92: 545-555.

Wright J 2011. Evaluating the use of 1080: predators, poisons and silent forests. Wellington, New Zealand, Office of the Parliamentary Commissioner for the Environment. 85 p. 